\title{
RELEVANSI PENERAPAN KURIKULUM 2013 DI SEKOLAH PADA MATA PELAJARAN FISIKA DAN HUBUNGAN DENGAN KINERJA INDIVIDUAL PENGGUNA(STUDI KASUS SMASE-KABUPATEN KOTABARU)
}

\author{
Muhammad Ali ${ }^{1}$, Radiatul Adawiah ${ }^{2}$ \\ ${ }^{1}$ Sekolah Tinggi Keguruan dan Ilmu Pendidikan (STKIP) Paris Barantai, Kotabaru, 72116, Indonesia \\ ali.alfatih09@gmail.com \\ ${ }^{2}$ Program Studi Pendidikan Matematika, STKIP Paris Barantai. Kotabaru, 72116, Indonesia \\ radiatuladawiahku85@gmail.com
}

Diajukan: 15 January 2021; Diterima: 20 February 2021; Diterbitkan: 30 April 2021

\begin{abstract}
Abstrak: Tujuan umum penelitian ini adalah untuk mengetahui sejauh mana relevansi penerapan kurikulum 2013 pada mata pelajaran fisika dan hubungan dengan kinerja individual pengguna. Metode penelitian ini merupakan metode deskriptif kualitatif melalui analisis data deskriptif persentase dengan tahapan pengembangan angket/kuisioner respon kepala sekolah, guru fisika dan peserta didik terhadap penerapan kurikulum 2013. Subjek penelitian ini adalah kepala sekolah, guru fisika dan peserta didik SMA Se-Kabupaten Kotabaru. Hasil dari penelitian ini adalah 1) Kesiapan siswa dalam melaksanakan kurikulum 2013 tidakberjalan dengan baik melihat dari hasil persentase yang rendah yaitu 29,45\%. 2) Kesiapan guru dalam melaksanakan kurikulum 2013 sudah berjalan dengan cukup baik melihat dari hasil persentase yaitu 59,05\%. 4) Kesiapan kepala sekolah dalam melaksanakan kurikulum 2013 sudah berjalan dengan baik melihat dari hasil persentase yang tinggi yaitu 73,27\%. Kesimpulan dari penelitian ini adalah penerapan kurikulum 2013 pada mata pelajaran fisika dalam hubungan kinerja individual masih cukup relevan.
\end{abstract}

Kata Kunci: Relevansi Kurikulum 2013, Respon, deskriptif kualitatif

\begin{abstract}
The general purpose of this research is to find out the relevance of implementing the 2013 curriculum in physics subjects and the relationship with individual user performance. This research method is a qualitative descriptive method through descriptive percentage data analysis with the stages of developing a questionnairelquestionnaire for the response of school principals, physics teachers and students to the implementation of the 2013 curriculum. The subjects of this study were school principals, physics teachers and high school students throughout Kotabaru Regency. The results of this study are 1) The readiness of students in implementing the 2013 curriculum is not going well, seeing from the results of a low percentage of $29.45 \%$. 2) The readiness of teachers in implementing the 2013 curriculum has gone quite well, judging from the percentage results, which is 59.05\%. 4) The readiness of the principal in implementing the 2013 curriculum has been going well, judging from the high percentage of $73.27 \%$. The conclusion of this study is that the implementation of the 2013 curriculum in physics subjects in relation to individual performance is still quite relevant.
\end{abstract}

Keywords: 2013 Curriculum Relevance, Response, qualitative descriptive

\section{Pendahuluan}

Tujuan pendidikan memiliki dua fungsi yaitu memberikan arah kepada segenap kegiatan pendidikan dan tujuan yang ingin dicapai oleh segenap kegiatan pendidikan yang tertuang dalam suatu tatanan yang disebut dengan kurikulum. Kurikulum 2013 merupakan pengembangan dan penyempurnaan dari kurikulum sebelumnya untuk merespon berbagai tantangan internal maupun eksternal. Salah satu alasan pentingnya Kurikulum 2013 adalah bahwa generasi muda Indonesia perlu disiapkan dalam kompetensi sikap, keterampilan, dan pengetahuan.

Kurikulum 2013 suatu proses pembelajaran menggunakan pendekatan saintifik, proses pembelajaran menyentuh tiga ranah, yaitu sikap, pengetahuan, dan keterampilan. Pendekatan saintifik merupakan pembelajaran yang mengadopsi langkahlangkah saintis dalam membangun pengetahuan melalui metode ilmiah. Menurut Dewantari (2015:2) dalam kurikulum 2013 hal 
yang paling menonjol adalah pendekatan dan strategi pembelajarannya. Proses pembelajaran dalam kurikulum 2013 dilaksanakan dengan menggunakan pendekatan ilmiah (scientific approach). Proses pembelajaran harus menyentuh 3 ranah, yaitu sikap (attitude), keterampilan (skill), dan pengetahuan (knowledge). Hal ini sesuai pendapat Sanjaya (2012), "Pendekatan yang berpusat pada guru menurunkan strategi pembelajaran langsung (direct instruction), pembelajaran deduktif atau pembelajaran ekspositori. Sedangkan, pendekatan pembelajaran yang berpusat pada siswa menurunkan strategi pembelajaran discovery dan inkuiri serta strategi pembelajaran induktif'.

Pelaksanaan Kurikulum 2013 dipandang sebagai kebutuhan yang mendesak. Oleh karenanya kurikulum tersebut sudah dilaksanakan secara terbatas mulai tahun pelajaran 2013/2014 pada sekolah-sekolah yang memenuhi persyaratan dan ditetapkan secara selektif. Tetapi pada tahun pelajaran 2015/2016 Kurikulum 2013 tersebut direncanakan dilaksanakan pada semua sekolah. Menurut Mendikbud (dikutip Marsigit, 2013), jika pelaksanaan Kurikulum 2013 ditunda maka taruhannya adalah masa depan generasi bangsa.

Penerapan Kurikulum 2013 di sekolah tidak terlepas dari kesiapan guru yang menjalankan roda pengajaran dan pembelajaran di sekolah. Oleh karena itu Guru diibaratkan sebagai ujung tombak pendidikan sebab guru secara langsung berupaya mempengaruhi, membina dan mengembangkan kemampuan yang dimiliki siswa. Sebagaimana dijelaskan oleh Kusumastuti, dkk. (2016:120) "bahwa setiap guru mengemban tanggungjawab secara aktif dalam proses pendidikan baik sebagai pengembang kurikulum maupun sebagai pelaksana kurikulum". Sebagai pelaksana kurikulum seharusnya guru dapat melaksanakan kurikulum dengan baik, karena dengan melaksanakan Kurikulum 2013 secara tepat akan menghasilkan proses belajar yang lebih baik yaitu suasana belajar megajar yang lebih aktif, kreatif dan menyenangkan berpusat pada peserta didik.

Berdasarkan dari hasil wawancara peneliti dengan beberapa kepala sekolah di kabupaten kotabaru mengatakan bahwa sekolah sudah siap melaksanakan kurikulum 2013, namun secara pengguna individualnya masih mengalami kendala dalam menerapkannya walaupun sudah diadakan pelatihan kurikulum 2013. Ada yang berkomentar kurikulum 2013 kurang relevan diterapkan, dan ada juga komentar sudah bisa diterapkan tergantung dari kesiapan guru.

Faridah (2014) melakukan penelitian dengan judul "Kesiapan Guru Dalam Implementasi Kurikulum 2013”. Dengan hasil penelitian pelaksanaan kurikulum 2013 masih menemukan kendala besar yang perlu segera ditangani yaitu kesiapan guru. Beberapa intervensi seperti pelatihan khusus dan klinik konsultasi pembelajaran sudah diluncurkan pemerintah untuk mengembangkan kompetensi guru.

Namun, hal itu belum cukup jika tidak dilakukan pengawasan dan perbaikan terus menerus. Bukan berarti mereka yang telah lulus pelatihan dapat langsung menerapkan kurikulum 2013. Pemerintah harus melakukan evaluasi secara teratur untuk meningkatkan kualitas guru.

Harapan dari penelitian ini mengetahui sejauh mana relevansi penerapan kurikulum 2013 pada mata pelajaran fisika dan mengetahui kendala penerapan kurikulum 2013 serta pemangkuh pendidikan bisa memberikan solusi terhadap permasalahan ini. Berdasarkan latar belakang yang telah dipaparkan di atas, maka perlu diadakan penelitian "Relevansi Penerapan Kurikulum 2013 Pada Mata Pelajaran Fisika dan Hubungan dengan Kinerja Individual Pengguna (Studi Kasus SMA Se-Kabupaten Kotabaru)". Adapun rumusan masalah pada penelitian ini yaitu Bagaimana Relevansi penerapan kurikulum 2013 terhadap pembelajaran fisika di sekolah dan kinerja individual. Tujuan khususnya yaitu untuk mendeskripsikan revansi penerapan kurikulum 2013 pada mata pelajaran fisika di sekolah.

\section{Metode Penelitian}

Penelitian ini merupakan jenis penelitian deskriptif kualitatif melalui tahapan pengembangan angket/kuisioner respon kepala sekolah, guru fisika dan siswa terhadap penerapan kurikulum 2013. Lokasi Penelitian ini dilakukan di 
Kabupaten Kotabaru dengan fokus penelitian pada Kepala sekolah, guru Fisika, dan Siswa SMA Se-Kabupaten Kotabaru. Subjek penelitian ini adalah kepala sekolah dan guru fisika, dan siswa SMA Se-Kabupaten Kotabaru.

Langkah-langkah yang dillakukan pada penelitian ini dimulai dengan persiapan. Untuk persiapan yang dilakukan pada penelitian dapat dilihat pada bagan di bawah. Sehingga alur dan rancangan penelitian di atas maka Persiapan yang dilakukan adalah mengumpulkan kajian pustaka yang mendukung penelitian dan menyiapkan segala sesuatu yang dibutuhkan dalam penelitian. Selanjutnya mencari data-data sekolah yang akan diteliti. Jika data yang diteliti sudah ada, dilakukan pemilihan subjek penelitian yaitu 10 orang kepala sekolah, 10 guru fisika SMA dari 10 sekolah yang dipilih dan 100 siswa dari 10 sekolah. Kemudian disusun instrumen penelitian yang terdiri dari lembar wawancara dan lembar angket/kuisioner respon kepala sekolah, guru fisika, dan respon siswa terhadap revansi penerapan kurikulum 2013 yang meliputi respon terhadap pembelajaran, penilaian, sarana dan prasarana, dan pelaksanaan kurikulum 2013.

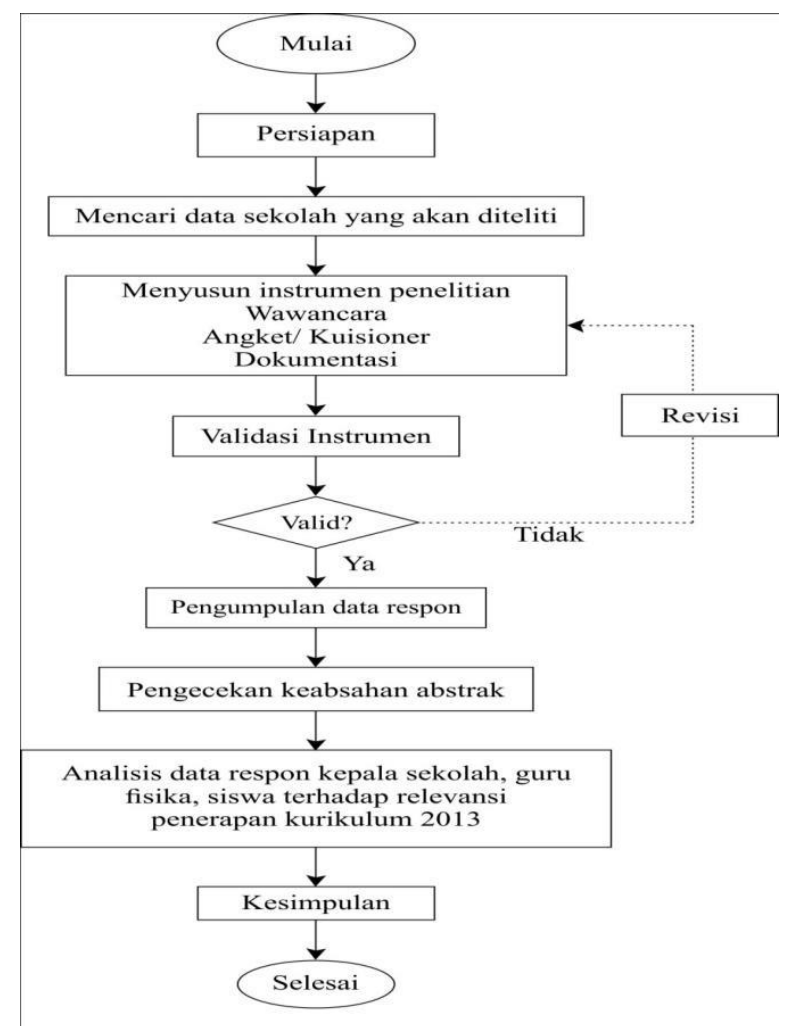

Gambar 1. Prosedur Penelitian
Sebelum instrumen diberikan kepada subjek penelitian maka dilakukan validasi dengan validator pilihan, mengenai gaya bahasa yang digunakan dan kesesuaian dengan respon kepala sekolah, guru fisika, dan respon siswa terhadap relevansi penerapan kurikulum 2013. Jika instrumen sudah valid maka langsung dilakukan penelitian di sekolah untuk mengumpulkan data yang diperlukan. Namun, jika instrumen belum bisa dikatakan valid akan perlu revisi kembali penyusunan instrumen penelitian tersebut sampai dikatakan valid.

Teknik-teknik pengumpulan data yaitu wawancara dan pemberian angket/kuisioner. Jika data-data yang diperlukan dari hasil penelitian di sepuluh sekolah sudah lengkap, maka dilakukan analisis data. Data yang dimaksud yaitu hasil dari wawancara dan pemberian angket/kuisioner yang hasilnya nanti dijadikan sebagai hasil dari analisis relevansi penerapan kurikulum 2013 terkait pembelajaran, penilaian, sarana dan prasarana, dan pelaksanaan kurikulum 2013. Kemudian hasil pengumpulan data dengan angket tersebut akan di analisis dengan tiga tahap analisis data kualitatif seperti yang dijelaskan oleh Miles dan Huberman (dalam Sugiyono, 2014:337-345) yaitu Reduksi Data (Data Reduction), Penyajian Data (Display Data), dan Penarikan kesimpulan dan Verifikasi (Conclusion Drawing/Verification).

Mereduksi data menurut Sugiyono (2010:92) mereduksi data berarti merangkum, memilih hal-hal yang pokok, memfokuskan pada hal-hal yang penting, dicari tema dan polanya, antara lain: 1) mengumpulkan data dan informasi dari catatan hasil kuesioner dan wawancara; 2) mencari hal-hal yang dianggap penting dari setiap aspek temuan penelitian. Selanjutnya penyajian data. Data yang disajikan dalam penelitian ini berbentuk rangkuman secara deskriptif dan sistematis dari hasil yang diperoleh. Langkah yang terakhir adalah verifikasi data atau menarik kesimpulan. Kegiatan yang dilakukan pada tahap ini yaitu: 1) menguji kesimpulan yang diambil dengan membandingkan teori yang dikemukakan pakar, terutama teori yang relevan, 2) melakukan proses pengecekan ulang mulai dari pelaksanaan pemberian 
kuisioner, wawancara, dan dokumentasi, 3) membuat kesimpulan untuk dilaporkan sebagai hasil dari penelitian yang dilakukan.

\section{Hasil Penelitian dan Pembahasan}

Data penelitian ini diperoleh dengan tiga cara, yaitu: (1) mendatangi sekolah yang menjadi tempat penelitian; (2) bertemu dengan Kepala Sekolah, guru mata pelajaran fisika dan siswa yang menjadi responden (3) kemudian memberika angket dan mengobservasi guru pada saat melakukan proses pembelajaran serta melakukan wawancara sebagai data pendukung pada penelitian ini.

Hasil dari penelitian ini adalah untuk mengetahui relevansi penerapan kurikulum 2013 pada mata pelajaran fisika dan hubungan dengan kinerja individual pengguna. Adapun hasil dari penelitian ini yang ditinjau dari pembelajaran, penilaian, sarana dan prasarana, dan pelaksanaan kurikulum. Analisis angket respon peserta didik dapat dilihat pada Tabel 1 berikut:

Tabel 1. Hasil Perhitungan Angket Respon Peserta Didik

\begin{tabular}{lccc}
\hline \multicolumn{1}{c}{$\begin{array}{c}\text { Aspek } \\
\text { Penilaian }\end{array}$} & $\begin{array}{c}\text { Jumlah } \\
\text { Item }\end{array}$ & $\begin{array}{c}\text { Rata- } \\
\text { rata } \\
(\mathbf{\%})\end{array}$ & Kategori \\
\hline $\begin{array}{l}\text { Pembelajara } \\
\text { n }\end{array}$ & 5 & 31,28 & Tidak Relevan \\
$\begin{array}{l}\text { Penilaian } \\
\text { sarana dan } \\
\text { prasarana } \\
\text { pelaksanaan }\end{array}$ & 4 & 30,85 & Tidak Relevan \\
$\begin{array}{l}\text { kurikulum } \\
2013\end{array}$ & 3 & 27,87 & Tidak Relevan \\
\hline \multicolumn{1}{c}{ Relevansi } & 5 & 27,84 & Tidak Relevan \\
\hline
\end{tabular}

Berdasarkan Tabel 1 di atas, hasil analisis angket respon peserta didik menujukan bahwa banyak yang mengeluh dan tidak setuju tentang penerapan kurikulum 2013, ini dapat dilihat dari hasil perhitungan angket respon peserta didik yang ditinjau dari aspek pembelajaran sebesar $31,28 \%$, aspek penilaian $30,85 \%$, aspek sarana dan prasarana sebesar $27,87 \%$, dan aspek pelaksanaan kurikulum 2013 sebesar 27,84\%. Jika dirataratakan hasil respon peserta didik sebesar $29,45 \%$ yang menunjukan pelaksanaan pembelajaran kurikulum 2013 yang dirasakan peserta didik tidak relevan. Oleh karena itu perlu diadakan evaluasi dan perbaikan mengenai pelaksanaan kirukulum 2013, sehingga peserta didik bisa merasakan pembelajaran yang menyenangkan dan bisa menumbuhkan inovasi dan kreativitas peserta didik.

Hasil analisis angket respon guru mata pelajran fisika (10 orang) ditinjau dari aspek pembelajaran, penilaian, sarana dan prasarana, dan pelaksanaan kurikulum dapat dilihat pada Tabel 2 di bawah ini:

Tabel 2. Hasil Perhitungan Angket Respon Guru Mata Pelajaran Fisika

\begin{tabular}{|c|c|c|c|}
\hline $\begin{array}{c}\text { Aspek } \\
\text { Penilaian }\end{array}$ & $\begin{array}{l}\text { Jumlah } \\
\text { Item }\end{array}$ & $\begin{array}{c}\text { Rata- } \\
\text { rata } \\
(\%)\end{array}$ & Kategori \\
\hline pembelajaran & 5 & 59,6 & Cukup Relevan \\
\hline Penilaian & 4 & 59 & Cukup Relevan \\
\hline $\begin{array}{l}\text { sarana dan } \\
\text { prasarana } \\
\text { pelaksanaan }\end{array}$ & 3 & 58 & Cukup Relevan \\
\hline $\begin{array}{l}\text { kurikulum } \\
2013\end{array}$ & 5 & 59,6 & Cukup Relevan \\
\hline
\end{tabular}

Relevansi

59,05 Cukup Relevan

Hasil perhitungan dan analisis angket respon guru mata pelajaran pada tabel 2 menunjukan bahwa aspek pembelajaran sebesar $59,6 \%$, aspek penilaian $59 \%$, aspek sarana dan prasarana sebesar $58 \%$, dan aspek pelaksanaan kurikulum 2013 sebesar 59,6\%. Hal ini menunjukan bahwa pernyataan guru tentang relevansi pelaksanaan kurikulum 2013 masih cukup relevan, namun ada beberapa guru yang kurang begitu setuju jika dilihat dari hasil analisis perhitungan angketnya. Menurut Ben B. Akpan (2010) memberikan gambaran bahwa guru dituntut untuk memahami pelaksanaan dan pembelajaran dalam kurikulum serta mengembangkan inovasi pada ranah eksperimen/peraktik dan komitmen dari guru untuk memainkan perannya agar pembelajaran lebih menarik.

Hasil penelitian yang telah dilakukan terhadap 10 guru mata pelajaran fisika di SMA Negeri se-Kabupaten Kotabaru yang menjadi subjek dalam penelitian ini, peneliti dapat mengumpulkan data melalui angket yang disebarkan dan diisi oleh guru mata pelajaran fisika itu sendiri, yang kemudian diberikan skor pada masing-masing item pada tiap 
aspek. Aspek pertama yaitu aspek pembelajaran yang disajikan dalam diagram batang berikut ini:

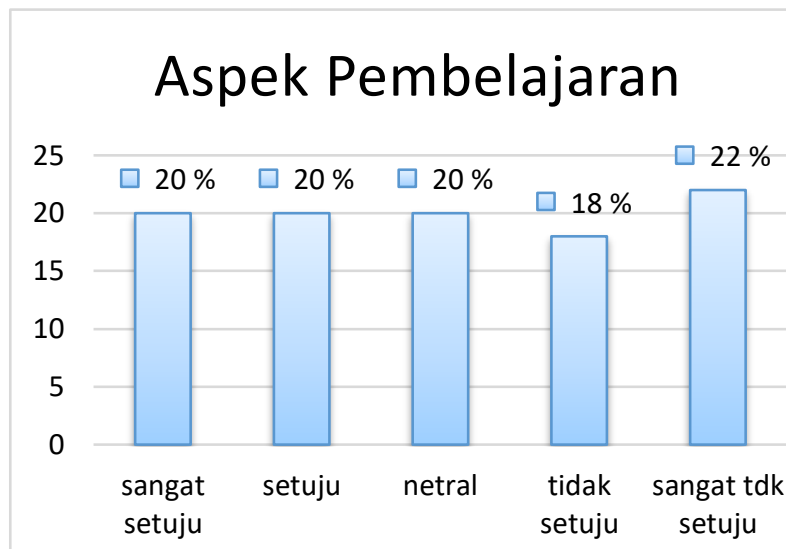

Gambar 2. Histogram Distribusi persentase Aspek pembelajaran

Berdasarkan analisis deskriptif dengan teknik analisis data deskriptif presentase dengan hasil nalisis angket respon guru mata pelajaran fisika pada aspek pembelajaran menujunjuk bahwa terdapat rata-rata 2 orang guru (20\%) sangat setuju, 2 guru (20\%) berada dalam kategori setuju, 2 orang guru $(20 \%)$ berada pada kategori netral, 1,8 rata-rata guru (18\%) yang tidak setuju dan rata-rata guru yang sangat tidak setuju berada pada 2,2 $(22 \%)$.

Data yang diperoleh dari angket yang disebarkan pada 10 responden dari 10 sekolah menunjukkan bahwa relevansi penerapan kurikulum 2013 dan hubungannya dengan kinerja individual masih cukup relevan pada aspek pembelajaran dengan presentase $59,60 \%$. Presentase tersebut menunjukkan bahwa, guru sebagian besar menerapkan Kurikulum 2013 dalam pelaksanaan pembelajaran sesuai dengan pengembangan Kurikulum 2013, yaitu mengenai pembelajaran siswa aktif, mandiri, kritis, pembelajaran berbasis pemecahan masalah, pola pembelajaran berbasis tim, penggunaan karakteristik pembelajaran yang disesuaikan dengan karakteristik kompetensi dan penerapan kurikulum 2013 yang dilaksanakan selama kegiatan belajar mengajar berlangsung.

Aspek selanjutnya adalah penilaian yang dapat dilihat pada Gambar 3 di bawah ini:

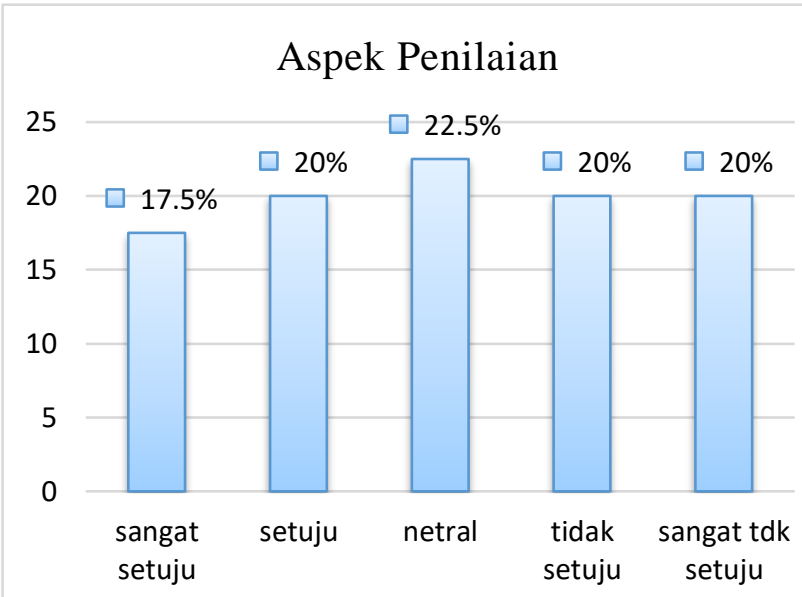

Gambar 3. Histogram Distribusi persentase Aspek Penilaian

Berdasarkan analisis deskriptif dengan teknik analisis data deskriptif presentase dengan hasil nalisis angket respon guru mata pelajaran fisika pada aspek penilaian menujunjuk bahwa terdapat rata-rata 1,6 orang guru (16\%) sangat setuju, rata-rata (2) guru $(20 \%)$ berada dalam kategori setuju, rata-rata $(2,4)$ orang guru $(24 \%)$ berada pada kategori netral, rata-rata $(2,6)$ guru $(26 \%)$ yang tidak setuju dan rata-rata $(1,4)$ guru yang sangat tidak setuju berada pada (22\%).

Data yang diperoleh dari angket yang disebarkan pada 10 responden dari 10 sekolah menunjukkan bahwa relevansi penerapan kurikulum 2013 dan hubungannya dengan kinerja individual masih cukup relevan pada aspek penilaian dengan presentase $59 \%$. Presentase tersebut menunjukkan bahwa, guru sebagian besar menerapkan Kurikulum 2013 dalam pelaksanaan aspek penilaian sesuai dengan pengembangan Kurikulum 2013, yaitu mengenai tata cara dan tahapan-tahapan dalam penilaian kurikulum 2013.

Aspek yang akan di analisis adalah aspek sarana dan prasarana yang dapat dilihat pada Gambar 4 berikut: 


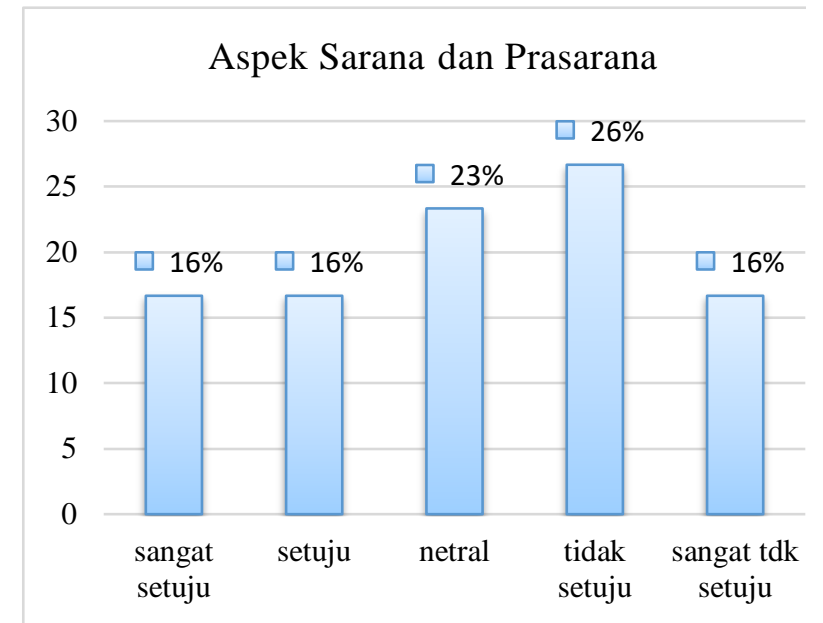

Gambar 4. Histogram Distribusi persentase Aspek Sarana dan Prasarana

Berdasarkan analisis deskriptif dengan teknik analisis data deskriptif presentase dengan hasil nalisis angket respon guru mata pelajaran fisika pada aspek Sarana dan Prasarana menujunjuk bahwa terdapat rata-rata 1 orang guru $(16 \%)$ sangat setuju, rata-rata 1 guru $(16 \%)$ berada dalam kategori setuju, ratarata 2 orang guru (23\%) berada pada kategori netral, rata-rata 2 guru (26\%) yang tidak setuju dan rata-rata 1 orang guru yang sangat tidak setuju berada pada (16\%).

Data yang diperoleh dari angket yang disebarkan pada 10 responden dari 10 sekolah menunjukkan bahwa relevansi penerapan kurikulum 2013 dan hubungannya dengan kinerja individual masih cukup relevan pada aspek Sarana dan Prasarana dengan presentase 58\%. Presentase tersebut menunjukkan bahwa, sarana dan prasarana dalam menerapkan Kurikulum 2013 sesuai dengan pengembangan Kurikulum 2013, yaitu mengenai kecukupan sarana dan prasarana dalam mendukung pelkasanaan kurikulum 2013.

Selanjutnya aspek yang terakhir yaitu aspek pelaksanaan kurikulum 2013. Aspek ini lebih jelasnya dapat dilihat pada Gambar 5 di bawah ini:
Aspek Pelaksanaan Kurikulum 2013

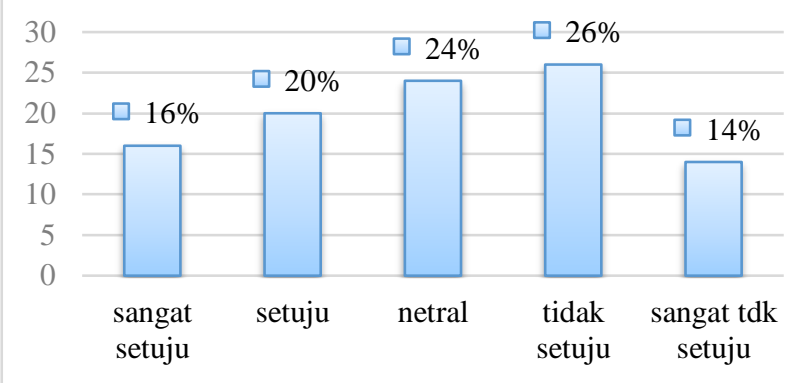

Berdasarkan analisis deskriptif dengan teknik analisis data deskriptif presentase dengan hasil nalisis angket respon guru mata pelajaran fisika pada aspek penilaian menujunjuk bahwa terdapat rata-rata 1 orang guru (16\%) sangat setuju, rata-rata 2 guru (20\%) berada dalam kategori setuju, rata-rata 2 orang guru (24\%) berada pada kategori netral, rata-rata 2 guru (26\%) yang tidak setuju dan rata-rata 1 orang guru yang sangat tidak setuju berada pada $(14 \%)$.

Data yang diperoleh dari angket yang disebarkan pada 10 responden dari 10 sekolah menunjukkan bahwa relevansi penerapan kurikulum 2013 dan hubungannya dengan kinerja individual masih cukup relevan pada aspek pelaksanaan kurikulum 2013 dengan presentase $59,60 \%$. Presentase tersebut menunjukkan bahwa, pelaksanaan Kurikulum 2013 yang dilaksanakan oleh guru di sekolah sesuai dengan pengembangan Kurikulum 2013.

Selanjutnya, perhitungan angket kepala sekolah (10 orang) yang mencakup pembelajaran, penilaian, sarana dan prasarana, dan pelaksanaan kurikulum dapat dilihat pada Tabel 3 berikut ini:

Tabel 3. Hasil Perhitungan Angket Respon Kepala Sekolah

\begin{tabular}{|c|c|c|c|}
\hline $\begin{array}{c}\text { Aspek } \\
\text { Penilaian }\end{array}$ & $\begin{array}{l}\text { Jumlah } \\
\text { Item }\end{array}$ & $\begin{array}{c}\text { Rata- } \\
\operatorname{rata}(\%)\end{array}$ & Kategori \\
\hline Pembelajaran & 5 & 72,4 & Relevan \\
\hline Penilaian & 4 & 73,5 & Relevan \\
\hline $\begin{array}{l}\text { sarana dan } \\
\text { prasarana }\end{array}$ & 3 & 74 & Relevan \\
\hline $\begin{array}{l}\text { pelaksanaan } \\
\text { kurikulum } 2013\end{array}$ & 5 & 73,2 & Relevan \\
\hline Relevansi & & 73,27 & Relevan \\
\hline
\end{tabular}


Berdasarkan hasil perhitungan dan analisis angket respon kepala sekolah mengenai relevansi pelaksanaan kurikulum 2013 pada tabel 3 di atas menunjukan bahwa aspek pembelajaran sebesar $72,4 \%$, aspek penilaian $73,5 \%$, aspek sarana dan prasarana sebesar 74\%, dan aspek pelaksanaan kurikulum 2013 sebesar 73,2\%. Hal ini menunjukan bahwa tanggapan kepala sekolah mengenai relevansi pelaksanaan kurikulum 2013 masih relevan. Hal ini sesuai pendapat Nana Sudjana (2008:117-118) mengatakan bahwa peranan Kepala Sekolah dalam pembinaan kurikulum sangat menentukan keberhasilan penyelenggaraan pendidikan di sekolah. Bahkan dapat dikatakan Kepala Sekolah yang bertanggung jawab penuh terhadap penyelenggaraan pendidikan di sekolah. Pendidikan dikatakan berjalan dengan baik apabila kurikulum potensial dilaksanakan di sekolah oleh semua staf, dan peserta didik yang terlibat didalamnya.

Hasil penelitian yang telah dilakukan terhadap 10 Kepala Sekolah di SMA Negeri se-Kabupaten Kotabaru yang menjadi subjek dalam penelitian ini, peneliti dapat mengumpulkan data melalui angket yang disebarkan dan diisi oleh Kepala Sekola itu sendiri, yang kemudian diberikan skor pada masing-masing item pada tiap aspek. Aspek pertama yaitu aspek pembelajaran yang disajikan dalam diagram batang berikut ini:

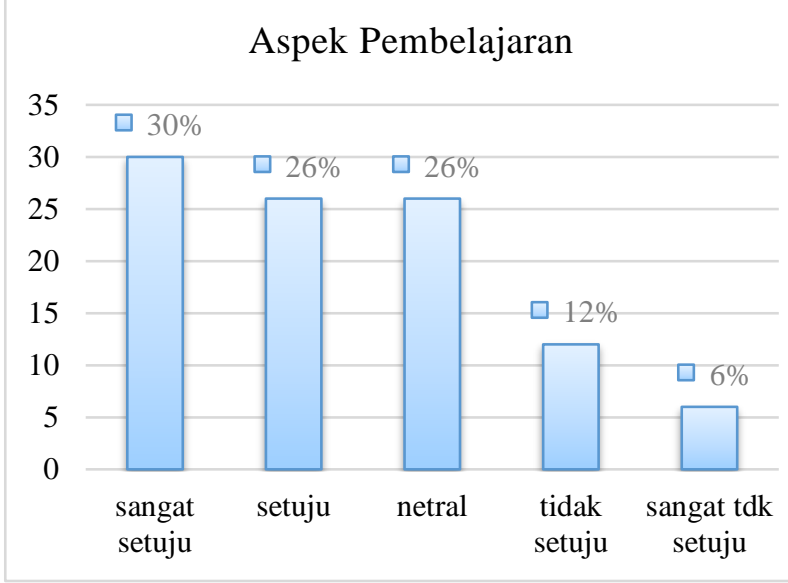

Gambar 6. Histogram Distribusi persentase Aspek pembelajaran

Berdasarkan analisis deskriptif dengan teknik analisis data deskriptif presentase dengan hasil nalisis angket respon Kepala Sekolah pada aspek pembelajaran menujunjuk bahwa terdapat rata-rata 3 orang guru (30\%) sangat setuju, 2 guru (26\%) berada dalam kategori setuju, 2 orang guru $(26 \%)$ berada pada kategori netral, rata-rata 1 guru $(12 \%)$ yang tidak setuju dan rata-rata 0,6 guru yang sangat tidak setuju berada pada $(6 \%)$.

Data yang diperoleh dari angket yang disebarkan pada 10 responden dari 10 sekolah menunjukkan bahwa relevansi penerapan kurikulum 2013 dan hubungannya dengan kinerja individual relevan pada aspek pembelajaran dengan presentase $72,40 \%$. Presentase tersebut menunjukkan bahwa, kepala sekolah dalam pelaksanaan pembelajaran sesuai dengan pengembangan Kurikulum 2013, yaitu mengenai pembelajaran siswa aktif, mandiri, kritis, pembelajaran berbasis pemecahan masalah, pola pembelajaran berbasis tim, penggunaan karakteristik pembelajaran yang disesuaikan dengan karakteristik kompetensi dan penerapan kurikulum 2013 yang dilaksanakan selama kegiatan belajar mengajar berlangsung.

Aspek selanjutnya adalah aspek penilaian yang dapat dilihat pada Gambar 7 di bawah ini:

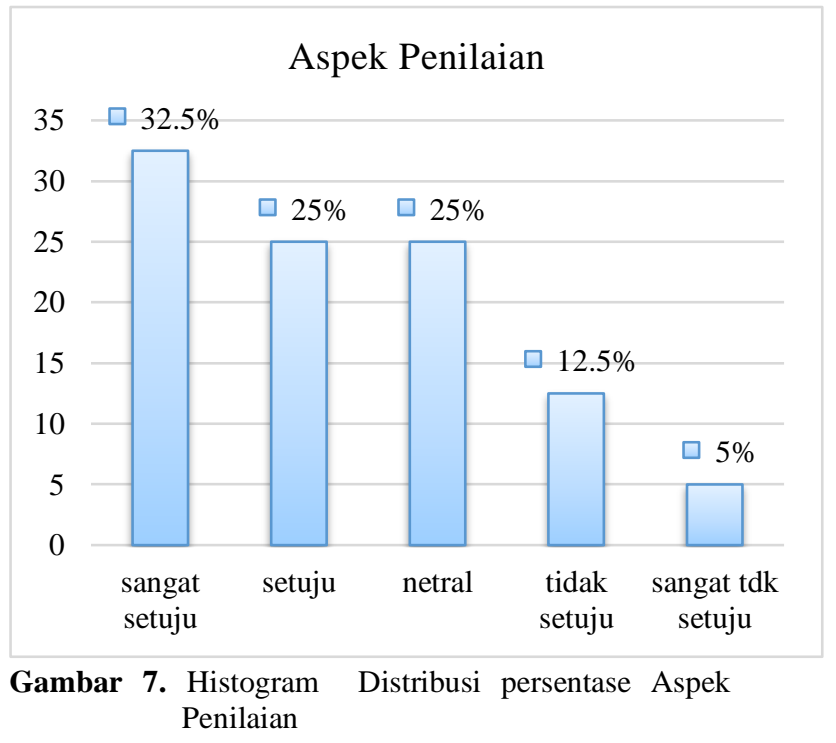

Berdasarkan analisis deskriptif dengan teknik analisis data deskriptif presentase dengan hasil nalisis angket respon guru mata pelajaran fisika pada aspek penilaian menujunjuk bahwa terdapat rata-rata 3 orang guru $(32,5 \%)$ sangat setuju, rata-rata 2 guru (25\%) berada dalam kategori setuju, rata-rata 2 orang guru $(25 \%)$ berada pada kategori netral, rata-rata 1 guru $(12,5 \%)$ yang tidak setuju dan 
rata-rata 0,5 guru yang sangat tidak setuju berada pada $(5 \%)$.

Data yang diperoleh dari angket yang disebarkan pada 10 responden dari 10 sekolah menunjukkan bahwa relevansi penerapan kurikulum 2013 dan hubungannya dengan kinerja individual masih cukup relevan pada aspek penilaian dengan presentase $73,5 \%$. Presentase tersebut menunjukkan bahwa, guru sebagian besar menerapkan Kurikulum 2013 dalam pelaksanaan aspek penilaian sesuai dengan pengembangan Kurikulum 2013, yaitu mengenai tata cara dan tahapan-tahapan dalam penilaian kurikulum 2013.

Aspek yang akan di analisis adalah aspek sarana dan prasarana yang dapat dilihat pada Gambar 8 berikut:

\section{Aspek Sarana dan Prasarana}

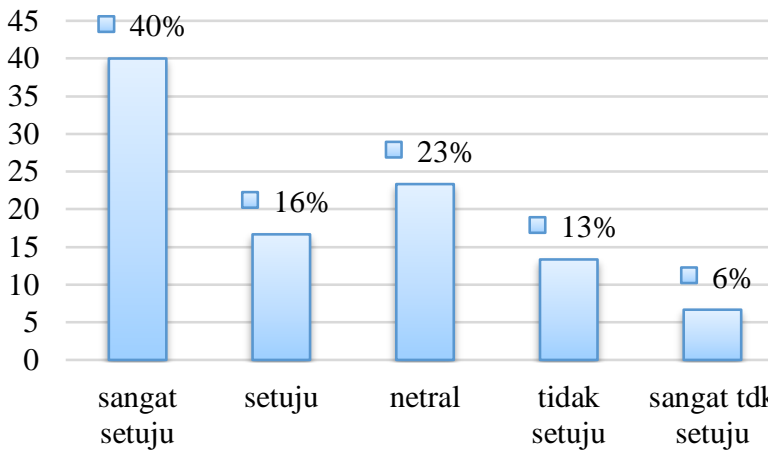

Gambar 8. Histogram Distribusi persentase Aspek Sarana dan Prasarana

Berdasarkan analisis deskriptif dengan teknik analisis data deskriptif presentase dengan hasil nalisis angket respon guru mata pelajaran fisika pada aspek Sarana dan Prasarana menujunjuk bahwa terdapat rata-rata 4 orang guru $(40 \%)$ sangat setuju, rata-rata 1 guru $(16 \%)$ berada dalam kategori setuju, ratarata 2 orang guru $(23 \%)$ berada pada kategori netral, rata-rata 1 guru (13\%) yang tidak setuju dan rata-rata 0,6 orang guru yang sangat tidak setuju berada pada $(6,6 \%)$.

Data yang diperoleh dari angket yang disebarkan pada 10 responden dari 10 sekolah menunjukkan bahwa relevansi penerapan kurikulum 2013 dan hubungannya dengan kinerja individual masih cukup relevan pada aspek Sarana dan Prasarana dengan presentase 74\%. Presentase tersebut menunjukkan bahwa, sarana dan prasarana dalam menerapkan Kurikulum 2013 sesuai dengan pengembangan
Kurikulum 2013, yaitu mengenai kecukupan sarana dan prasarana dalam mendukung pelkasanaan kurikulum 2013.

Selanjutnya aspek yang terakhir yaitu aspek pelaksanaan kurikulum 2013. Aspek ini lebih jelasnya dapat dilihat pada Gambar 9 di bawah ini:

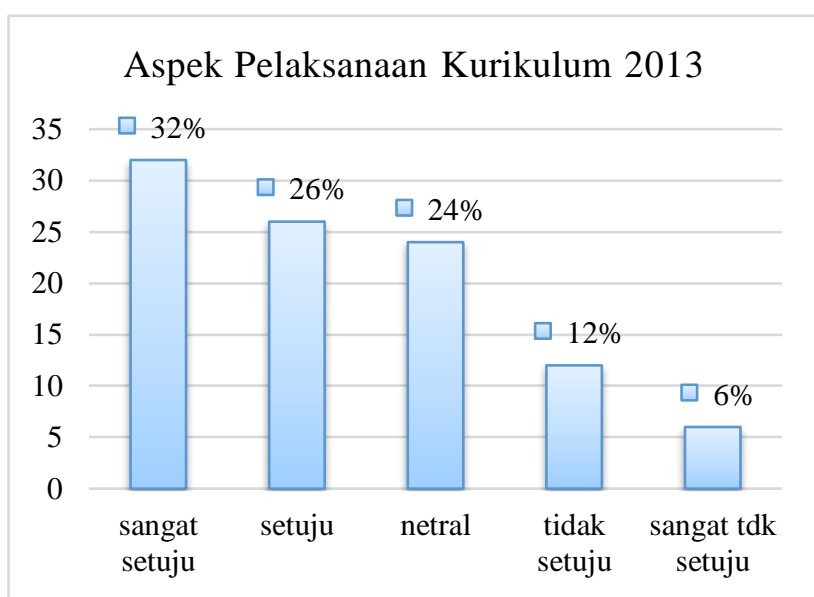

Gambar 9. Histogram Distribusi persentase Aspek Pelaksanaan Kurikulum

Berdasarkan analisis deskriptif dengan teknik analisis data deskriptif presentase dengan hasil nalisis angket respon guru mata pelajaran fisika pada aspek penilaian menujunjuk bahwa terdapat rata-rata 3 orang guru $(32 \%)$ sangat setuju, rata-rata 2 guru (26\%) berada dalam kategori setuju, rata-rata 2 orang guru $(24 \%)$ berada pada kategori netral, rata-rata 1 guru (12\%) yang tidak setuju dan rata-rata 0,6 orang guru yang sangat tidak setuju berada pada (6\%).

Data yang diperoleh dari angket yang disebarkan pada 10 responden dari 10 sekolah menunjukkan bahwa relevansi penerapan kurikulum 2013 dan hubungannya dengan kinerja individual masih cukup relevan pada aspek pelaksanaan kurikulum 2013 dengan presentase $73,20 \%$. Presentase tersebut menunjukkan bahwa, pelaksanaan Kurikulum 2013 yang dilaksanakan oleh Kepala Sekolah di sekolah sesuai dengan pengembangan Kurikulum 2013.

Dari hasil analisis masing-masing aspek pada kuesioner mengenai relevansi penerapan Kurikulum 2013 dalam hubungan kinerja individual, dilihat dari hasil perhitungan angket respon peserta didik yang ditinjau dari aspek pembelajaran sebesar $31,28 \%$, aspek 
penilaian $30,85 \%$, aspek sarana dan prasarana sebesar $27,87 \%$, dan aspek pelaksanaan kurikulum 2013 sebesar 27,84\%. Jika dirataratakan hasil respon peserta didik sebesar $29,45 \%$ yang menunjukan pelaksanaan pembelajaran kurikulum 2013 yang dirasakan peserta didik tidak relevan.

Kemudian Hasil perhitungan dan analisis angket respon guru mata pelajaran pada tabel 2 menunjukan bahwa aspek pembelajaran sebesar $59,6 \%$, aspek penilaian $59 \%$, aspek sarana dan prasarana sebesar $58 \%$, dan aspek pelaksanaan kurikulum 2013 sebesar 59,6\%. Hal ini menunjukan bahwa pernyataan guru tentang relevansi pelaksanaan kurikulum 2013 masih cukup relevan, namun ada beberapa guru yang kurang begitu setuju jika dilihat dari hasil analisis perhitungan angketnya.

Selanjutnya Berdasarkan hasil perhitungan dan analisis angket respon kepala sekolah mengenai relevansi pelaksanaan kurikulum 2013 pada tabel 3 di atas menunjukan bahwa aspek pembelajaran sebesar $72,4 \%$, aspek penilaian $73,5 \%$, aspek sarana dan prasarana sebesar $74 \%$, dan aspek pelaksanaan kurikulum 2013 sebesar 73,2\%. Hal ini menunjukan bahwa tanggapan kepala sekolah mengenai relevansi pelaksanaan kurikulum 2013 masih relevan. Hal ini sesuai pendapat Nana Sudjana (2008:117-118) mengatakan bahwa peranan Kepala Sekolah dalam pembinaan kurikulum sangat menentukan keberhasilan penyelenggaraan pendidikan di sekolah.

\section{Kesimpulan}

Kesimpulan diperoleh dari penelitian ini adalah sebagai berikut: (1) Kesiapan siswa dalam melaksanakan kurikulum 2013 tidakberjalan dengan baik melihat dari hasil persentase yang rendah yaitu $29,45 \%$. (2) Kesiapan guru dalam melaksanakan kurikulum 2013 sudah berjalan dengan cukup baik melihat dari hasil persentase yaitu 59,05\% .

Kesiapan kepala sekolah dalam melaksanakan kurikulum 2013 sudah berjalan dengan baik melihat dari hasil persentase yang tinggi yaitu $73,27 \%$.

\section{Daftar Pustaka}

Alawiyah, Faridah. (2014, Agustus). Kesiapan Guru dalam Implementasi Kurikulum 2013. Info Singkat Kesejahteraan Sosial, IV(1), 912. Retrieved 10 September 2019, from http://berkas.dpr.go.id/puslit/files/info_singk at/Info\%20Singkat-VI-15-I-P3DI-Agustus2014-56.pdf

Ben B. Akpan (2010). Innovations in Science and Technology Education through Science Teacher Associations. Science Education International Vol.21, No.2, September 2019, 67-79.

Dewantari, Puspita M.A. 2015. Identifikasi Kesulitan Guru Ipa Dalam Melaksanakan Pembelajaran Kurikulum 2013 Di Smp Negeri 1 Wonogiri Tahun Pelajaran 2014/2015. Fakultas Ilmu Pendidikan Universitas Negeri Yogyakarta. (http://eprints.ums.ac.id/34337/1/NASKAH \%20PUBLIKASI.p df) diakses pada tanggal 26 Juli 2019).

Kusumastuti, Ayuk, dkk. 2016. Faktor-Faktor Penghambat Guru dalam melaksanakan Kurikulum 2013 pada Pembelajaran Akuntansi di SMK Negeri 3 Surakarta. Jurnal Pendidikan Akuntansi, FKIP Universitas Sebelas Maret (online), Vol. 2, No. $\quad 1, \quad$ hlm. 118-133, (file:///C:/Users/Aspire/Downloads/787616547-1-SM.pdf.diakses pada tanggal 27 Juli 2019).

Marsigit, 2013, Tantangan dan Harapan Kurikulum 2013 Bagi Pendidikan Matematika, Seminar Nasional Matematika dan Pendidikan Universitas PGRI Yogyakarta Yogyakarta, 18 Juni 2019

Sanjaya, Wina. (2008). Strategi Pembelajaran Berorientasi standar Proses Pendidikan. Jakarta: Kencana Prenada Media Goup.

Sugiyono .2010 .Memahami Penelitian Kualitatif. Bandung : Alfabeta.

— . 2014 .Metode Penelitian Pendidikan, Pendekatan Kuantitatif, Kualitatif,dan $R \& D$. Bandung : Alfabeta.

Sudjana, Nana. 2008. Pembinaan dan Pengembangan Kurikulum di Sekolah. Bandung : Sinar Baru Algensindo. 